\title{
Feminising politics: notes on material and temporal feminist modal logics in action
}

\section{Felicity Colman \\ University of the Arts London}

Received: 19/10/2019

Accepted: 02/12/2019

DOI: https://doi.org/10.1344/jnmr.v1i1.29895

\begin{abstract}
Feminist activism aims to work to change the inequitable structures of the world. But feminists themselves get bound up in actions and intentions that are tied to their large object of critique (the patriarchy, the planet, the media, the canon, etc), and the micropolitics of the subjects constituting and constituted by those objects can be swept up in humanistic rhetorical gestures and words. How can we teach the modalities and the genealogy of feminist actions that offer tools for everyday living and for a community practice, and which also offer some ways to engage with the affective matter of the world from a posthumanist perspective, and thereby work to shift cultural attitudes? In addition to the valuable work done by those that tirelessly figure methods of communicating social inequities, the work of research led feminist informed teaching and governance can not only excavate the histories of social, political, speciesist, and biological inequities, but also offer a critique of these positions by the terms of their epistemological construction, and provide different modalities of practice. This article focuses on the latter, discussing how we might design curriculum and engage a pedagogy of recognition for a feminist modal ethics. How modes of feminist new materialist practice take the questions of affect, and agency, to enable ethical political practices is a pressing concern for many communities concerned with generating a planetary ethics. How new materialist methodology is useful for thinking the vernacular political reality was the topic of an
\end{abstract}


intensive discussion and debate that took place in November 2017 in Barcelona. Taking an example of the concrete work undertaken by Barcelona Councillor Gala Pin in relation to the neighbourhood of Ciutat Vella, the article proposes that we explore and extend the genealogy of a feminist modal logics.

\section{Keywords}

Affect, Arendt, Barcelona, Ciutat Vella, feminist, Gala Pin, Grosz, new materialism, modality, temporality

\section{Introduction: Modal logics in an age of neoliberalism}

In the second decade of the 2000s, the question of political emancipation came to a head with many cultural, economic, and ethical schisms appearing across mainstream political public debates. Which communities were actively engaging in the political governance of life, and who were claiming to be political, but being disengaged? Was 'democracy' really secular, and indeed 'democratic' in its processes? If an 'individual' or community fundamentally disagreed with another's cultural beliefs, or planetary practices (distribution of resources, ecological care, and so on), did that give them 'the right' to act in a hostile, aggressive, or violent manner as a reaction toward different sentient values? Perhaps a better way to frame the issues would be to ask what are the modalities at work here, driving these narratives, and generating these values? If the domains of governance, the law, the work-place, and the media are expressing events in the world in terms of 'post-truth'; 'post-race'; 'post-secular,' and post-human' etc., then there is more than just an articulation of the histories of ideologies, legal frameworks, gender relations, and ecological data required to engage. The world is not a simple place, and the complexities of its conglomerations, constructions, and dynamic matter require us to not just teach its domains, but to teach how to think the temporality of its movements, and the actions of its vectors. 
Working with the modalities of feminist actions, enables us to firstly capture the patterns of feminist movements, and then secondly, explore how the type of modal frameworks of different feminist new materialist methods offer concrete ways in which to not just think through or with a political event, but offer practical tools for confronting the inequity, or predicated moment of the modal. Modal logics belong to a family of philosophical logics that assist us in thinking, narrativizing, and acting according to the conditions and situations we experience, and which determine that situation in the world. Modal logic can be purely analytical, but here I draw on metaphysical modal models (cf. Grosz, 1998; Stang, 2016), with the intention of developing a feminist modal logics. Modalities frame the questions of possibilities (what if we all voted for equality), and the factual accounts of life (here are the harsh conditions that refugees of war must endure). A feminist modal logics is one concerned with the ethics of relational conditions. Questions of agency and affect as material, and as power relations - are what come to constitute these conditions.

The United Kingdom held a public vote to leave the European Union in 2016 and the Brexit was voted for after an anti-immigration (economic), and nationalist-cultural campaign focus by those pushing both to leave and to remain. In the 2016 United States presidential election an openly racist, sexist, and misogynist president was elected on the a nationalist and populist (cultural backlash against the 'non' nationalist values) rhetorical platform. Bitter and divisive public debates followed both of these events (and other similar events in Austria, Chile, Poland, to name a few where populist parties entered into forming coalition of leading governments), with the agency of the communication tools of governments, politicians, and the 'media' held to blame for the dis-information and ideological debates surrounding governance modes, and their legal validity. The cultural divides that populist and nationalist ideologies work with are predicated on gender, but also by ethnicity, age, ability, class, and economic status; above all, a hatred of difference, and a desire to curtail freedoms of individuals and of certain groups of people. This political narrative of restricted life took form in the first twenty years of the 21 st century, with those ideological signals found in political and public behaviours recalling the pre-fascist movements across Europe in the 1930s (pollical rallies; calls against different ethnic 
and minority groups; protectionist moves with the aims of limiting and controlling free trade and restrictions and tighter surveillances imposed on the movement of people). The affective agency of political communications are seen in countless such examples of the processes of national governance politics in action, and feminist political theorists and philosophers were quick to note these shifts in governance as patterns of neoliberalist modes, and offer analyses of their social implications (cf. Brown, 2017; Fraser, 2016; Patel \& Connelly, 2019). The ontological modal processes of hate regimes are based on populist narratives of the world; engendering hierarchically structured societies, economically biased towards barelythere majority politics that advocate 'post-truth' conditions (Jasanoff \& Simmet 2017). This legitimation of truth and of reality is indeed a crisis - that is generative of increasingly violent actions - that undermines the sense of a future as being socially cohesive and welcoming for all people, and one that endangers the abundant fecundity of the planet demonstrated by its lack of care for the natural environment (IPCC 2018). Instead, vernacular and indeed, any sense of "future societies" are expressed as "social," rather than "political" places where the State is devised as a "giant household" to maintain its sovereign citizens (Brown 2017: 118). The problem with this of course, is that it tends to be exclusionary on the basis of "not-family"; "not one-of-us" type of family; not to mention the enabling of the pathology of nationalism, generative of hatred of 'others' (cf. Braidotti, 2008; Fraser, 2016). There is such power in naming and providing inclusion in a "familial" community, and conversely, the agency of exclusion or difference (real or imagined) has terrible consequences. This 'truth' of the everyday of the early part of the twenty-first century is not the utopia that was imagined at the end of the last century; rather the 'truth' is predicated on data sets of human capital within the algorithmic condition (cf. Colman et.al, 2018; Dixon-Román, 2017). Feminist actions continually strive for representation at the table - to be able to counter the need for continuing conflict and refuse the use of military violent actions, address the need for better education of all in issues of diversity and difference, address the need for better health care, address the unequal distribution of resources, and undertake better planetary management of the world. Equality and diversity in leadership, management, and at all levels of political and 
social governance is a priority for feminist actions in the face of the bias and noninclusive, and violent agendas of populist ideologies.

How are we to understand the nationalist and populist mode of relation today, as it continues to affect the ethical and compassionate understanding of difference in the world? The Philosopher Hannah Arendt in her 1951 book The Origins of Totalitarianism, describes the processes of what we describe now as genocidal political domains; the results of colonial and European imperialism which continue under economically sanctioned fora that are related to modes of militarism which are likewise contained into specific territories (Arendt, 1958, p.123). In the post 9/11; 2001 decades, the vernacular conditions for the flourishing of the pathologies of totalitarianism are enabled in an even more intensive way; with digital algorithms communicating the ideological dogma of politicians who are intent on restricting freedoms for an ideally homogenous people messaging the divisive rhetoric slightly faster than the printed presses' propaganda posters of the previous century. Arendt's thesis is that totalitarian rules in motion; unlike a building it is structureless, but in its 'movement' (in the literal sense of a political party's movement), modes of totalitarianism destroy old frameworks even as they create new authoritarian territories in an endless cycle of restructuring (Arendt, 1958, p.398-99). Arendt's insights into the how totalitarian ideologies emerge through new authoritarian practices that engender propaganda through political controls and social communications describe the stages of how a political framework is dynamic, and not only the result of singular figures who push for certain positions, but forms through a synthesis of behaviours and events. Arendt comments: "Totalitarian movements are possible wherever there are masses who for one reason or another have acquired the appetite for political organization." (1958, p.311) Arendt argues that ideological reasoning is "emancipated from the reality that we perceive" (p.470) and describes: "Once the movements have come to power, they proceed to change reality in accordance with their ideological claims." (p.471)

References to Arendt's work on Totalitarianism in public media forums became noticeable after the 2016 political events. Mainstream media including the American 
business journal Forbes, and the British newspaper The Guardian regularly invoked Arendt's work, to try to provide for their readers a framework for the authoritarian rhetoric that was winning the popular vote, and radically shifting the cultural and political landscape (cf. Denning, 2016; Illing, 2019). In addition to thinking of the agency of political movements upon communities of minority groups, for vulnerable groups of women, girls, and for those identifying as transgender women, the agency of neoliberalism's economic governance of and upon their lives needs to be accounted for and protected against the forces that only wish to profit from them as a 'living capital body' (Colman, 2016, p.189), but not care for them in any ethical manner (cf. Brown, 2017).

External forces, such as the movement of totalitarian forces described in Arendt, and the internal governance of bodies by neoliberal; neocapitalist forces, operate as material modalities. By this, I mean that the models of neoliberalism - including their frameworks for assembling raw capital - manipulate sentient and non-sentient matter through a political agency that aims to produce the maximum profit through control over the production of things, information, and concepts under the rules of the marketplace, with little or no regard for the ethics of their production. Models that use material modalities refers us to the material conditions of a society. Material modal conditions thus point us toward what is the 'truth' being constructed in any given social situation, as the material includes the legal, as well as the "feasible"; "factual actuality" in terms of the technological conditions of the material (Poser 2013: 111). 1 As such, the very construction of a material modality offers itself as both a recognisable pattern or paradigm, but further, and provides, through analysis of the artefacts and type of use of matter, a range of processes, methods and tools that can be deployed to create new forms and new conditions for living.

1 For example, to describe a material modality includes consideration the kinds of contemporary technological conditions that give rise to social and political situations; the kind of technology Marx addresses in terms of worker's conditions in the industrial era of the 1840 s is very different to the digital-industrial work situation of 2010s. 


\section{Feminising politics: materialist model logics}

The meeting of new materialist feminist thinkers in Barcelona in 2017 proposed an alternative model for feminist education in neoliberal times. Instead of thinking "crisis", they joined to listen and respond to various new materialist models of thinking how agential forces can work together; relationally - to both model and produce better ways of living, being, thinking, and planning together - as communities. The questions this community of scholars, activities, and artists debated included: How to recognise the pathways of totalitarianism? How to avoid the pitfalls of living in neocapitalist economies? How to stay positive in the face of shifting political landscapes debating the old and dangerous issues of national identity? Most importantly, how to activate new ways of living? The group shared ideas, examples, methods about how to do this. "We" as a group are implicated in the creation and maintenance of this situation that "we" also inherited. How should we be forming governance structures that prioritise care and compassion rather than ignorance and hatred; fear of difference, and fear of change? How do we teach in a post-truth world? What tools we teach to deal with these conditions are incredibly important. An activism cannot just be a series of voices and disruptive actions. An ethical activism is one committed to a genuine ethics of care, the critique of unethical forms of agency of the infrastructural organisation of matter, and a desire to see diversity flourish.

A clear example of a new materialist modelling came from a discussion between politician and activist Gala Pin, and feminist curator and activist, Whitney Stark.2 Stark spoke of her work with the Reclaim our Pride movement, and the strategies around working outside of non-ethical funding models, and of how to do collective work safely in the face of extreme political affects that endanger freedom (Stark, 2017). Given the location of the meeting in Barcelona on 2017, these comments on practicing safety in collective public situations were timely. Within this setting, the

2 November 20-22, 2017, 4th New Materialism meeting Training School, "Art \& Activism" at Arts Santa Monica, Barcelona, Spain. Conversation between Gala Pin, councillor for neighbourhood of Barceloneta, Ciutat Vella, Barcelona. Whitney Stark, research fellow at BAK, basis voor actuele kunst, Utrecht. The moderator of this conversation was Ana González Ramos. Transcriptions of conversation by F.Colman. The Training School was funded by COST Action IS1307 New Materialism: Networking European Scholarship on 'How Matter Comes to Matter'. 
discussion focussed on the work of Councillor Gala Pin, who spoke of Barcelona's interculturality plan, which is mapped out in the official 'Economic Development Plan of Ciutat Vella 2016-2021' (ECV, 2016). This plan seeks to address the complexities of the Ciutat Vella neighbourhood. In particular, Pin spoke of the economic stresses on the multiple communities living particularly in the area of La Rambla, which have faced the brunt of neocapitalist expansion, with dire consequences for the community (see Jiménez-Pacheco, 2018, p.93-95; Degen, 2017).

Pin described the kinds of strategies used to 'make a different reality for women' who live in her neighbourhood, particularly around El Raval. Pin described how this area had more than 80 different types of communities living closely together - comprised of a range of different ethnicities, practicing different cultural beliefs, and using different languages - but also making its own self-community through what she described as 'co-living.' Speaking of this recent work on neighbourhood cohesion, Pin described aspects of the education plan and further, providing a specific example of environmental planning as a feminist. Pin spoke of two kinds of education issues for her neighbourhood; the first being ensuring gender equality in schools, given the second point of the diversity issues outside of the school yard. $52 \%$ of the population is from non-Spanish backgrounds, and a majority of these include women that stay at home to work are migrant women. For the women who live in La Barceloneta, many do not speak Catalan (the local language) or Spanish (the official language). They are mothers whose children are entered into a language education system not their own. The children go to school and come home working in the language of Barcelona, which their mothers can become more and more isolated. The majority of women's concrete daily unpaid work is in the labour of housework and of mothering. The education programme in the neighbourhood came up with the idea to offer the original (natal) language to the children, and Catalan language to the mothers; so that both groups are able to participate in the significant cultural situations in which they are immersed. Many of these women, said Pin, have no other connection to the city other than with the school that their children attend, so the council also offers programs for intercultural mediation, in order to integrate with Catalan parents. In addition, there are many programmes that the council runs 
extending to work around issues of gender related violence, and the access of all genders, including transgender, to medical support (Pin, 2017).

External and internal community politics thus cause a range of affects to be enacted upon individuals and social groups. In addition, as Pin described, the external challenges for this community include not only the extremes of social inequity posited by the tourist and disparities between economic factors in the neighbourhood, but the larger external political instabilities that impact directly and often most harshly upon vulnerable women. Security for women and girls in communities is a global problem, but in Barceloneta, the security factors encompass the neighbourhood and also aggressive public infrastructures and their affective manifestations (mass tourism), the media, and political arenas; such as changes in Government policies, recent State withdrawal of funding, which halts large policy work, together with anxieties over personal safety, and economic worries after the La Rambla attack (August, 2017).

To counter the neighbourhood's feeling of political instability and restlessness, Pin's multi-modal strategies worked on the need to enable collaboration of the intra-affects between actors in the community, manage the gender politics of all stakeholders in Ciutat Vella, and simultaneously enable the creation of a self-identity within the community. First, she said was to discuss with her team: "How do you gain confidence with the people who have heard promises many times? - confidence has to be built - you must show with practical results what your position is" (Pin, 2017). The second main strategy was one common to all grassroots feminist thinkers; to find out from those marginal yet inside a situation what is their experience and use of an environment. For both strategies, both Pin and Stark advocated using theory as 'tools' for education on issues of diversity, equality, and intercultural positive practices.

Pin described an example of where she and her team worked together on a specific project of constructing playgrounds for the heritage sites in Barcelona. Working with different community members including women with young children and nursing babies, who needed to access a playground near their home, which in Ciutat Vella 
is always in close proximity to an historical site with heritage significance, and is a place that attracts a lot of visitors. The built environmental questions for a playground at a heritage site were: How could some of the women be able to be in a public space, yet be comfortable, be secure, at the same time as a wide range of tourists and officials would be occupying the space? The result was to build an environment in consultation with the women who would use it that itself was a physical, material enabler of different modes of engagement; offering a shield against prying eyes, but multiple vantagepoints for seeing the matter that mattered: for the carer's supervision of the children; comfort for the female perspective; and for the tourist's sight of the heritage site/s.

The material question developed through consultation became: How do you design a space that is useful for tourists and for communities? This is a material modal question in that it is concerning the relationality of the matter. Significant for educators to note, a relational modal is different to other forms of modal questions (such as contingency and necessity) (see Poser, 2013; Colman, 2019). Pin is considering the matter of the site itself as well as the human elements in order to devise a response to the intra-affects of the community politics that arise - in this case-from the activities of site sharing as a community. Amongst others, these affects include fear (individual women in public), as well as desire (that of the child wishing to play; the carer wishing to partake of the community; the tourist wishing to engage in a heritage site). Pin gave this example of the design of a collaborative built environment as a way of educating on 'feminising politics.' This, as both she and Stark discussed, it is not just a matter of expressing the actions being engaged - as we might with a range of political theories that name patterns of actions without either offering countermeasures, or understanding the consequences of demonisation (see Glaser, 2018). Rather, as Pin described, 'the action is not the goal [of a feminist politics]'. Rather, it is 'in the address of the affects -and how to use them' where the feminist space can be made. Pin stressed that 'talking about affects like anger and hate is not productive', but rather consideration here is not only observing the action making affects (which belongs to a different modality), but also asking the questions: 'how affects are mobilised?'; 'how do you use affects?' To this, Whitney Stark added that 
'we often discuss the form and structure but not the ethics of the occupation of the form; so that it is not co-opted' (Stark, 2017). All of these factors contribute to our understanding of the material modalities that affect the relations of infrastructures, materials, and community groups. Naming and questioning those modalities helps educate on the kinds of material conditions that organise how a community is living. In this way Pin's focus on the material modalities of her neighbourhood, offers an ethical practice that critically negotiates a pathway through the oppressive agency of neoliberal forces.

Consideration of the logical modality (the necessities of a situation, and also the possibilities) governing the material modality of a community further enables a more accurate measure of the social conditions, enabling decisions concerning positive and ethically responsible action. Feminising politics as the strategy practiced by both Pin and Stark (also found in the latter's work with different community groups) embraces this understanding of how the conditions of a society are governed. Feminising politics means engaging material modalities that are responsive to the different governance strategy levels, and the different community experiences, and the different social and cultural backgrounds participating in those communities, and the genealogical trajectories of the people, other sentient creatures, and materials, and the material and social infrastructures that create that communal environment. Each of these things affect the agency (as power) of a community and larger society. 3 Once the agency of specific human elements, materials, governance of them (eg; who controls the matter of the heritage site; its natural ecology - the plants and animals that might also reside in it; the tourist market; the physical estate of a neighbourhood, infrastructural controls etc.); all of the intra-activities and potential and actual affects are identified and mapped out, then a view of how participation and the kinds of activities that might involve a number of different activities and actors can be consolidated. As Jiménez-Pacheco discusses (and diagrammatises), the

3 "Agency" holds a very specific meaning in new materialist theory; and to invoke it refers us to consideration of infrastructural powers, and their affects in operation (cf. Bargetz, 2018; Colman 2018). 
complexities within this neighbourhood offer a study of material modalities that require particular strategies in order to address their internal processes and systems as well as - as Pin identifies - their conglomerate infrastructures which can and are being utilised to offer educational as well as logical modes. Jiménez-Pacheco (2017) observes that: 'if the Rambla is not in essence a meeting space, but rather a repeated space of flows, the road towards its neighbourhood appropriation becomes more complex' (p.95). Pin's practice is to 'make politics to transform reality', and she works in this vein to change of existing structures or remove them, uses the strategies of feminising politics as tools to make changes, and she stresses that there are different ways to be productive, and that consolidation of the work happens over time; and it may happen slowly. Overtime, things change, and their affects may be experienced and used in different ways - for example, the long term affects of children and their carers interacting in the Barcelona education programme may not be seen for a while.

Affect belongs to a range of modalities that are used to express conditions of change in the world, and the cognition of those worlds. As a relational modality, affects chart the shifts in ethics and forces, (of social, industrial political-ecologies), so tracing the genealogies of affects provides further cues for feminising politics. The material modality used in feminising politics is one of the transformation of affects. The modal sets up the ethical relation between the modal (in this case, the model of governance) and its use. An affect is a tool, that is usually used to describe some kind of force or agency. It can be used to describe artefacts (the children's playground), but it is also the result of matter as ecofacts; such as the affect of a warm light shining upon the seedling; an affective agency is enabled. If we describe affect in terms of events, then through attention to their modal conditions can provides a more robust account of their situation. From events come affects and feelings - in relation to the political situations that we find ourselves in our own homes and communities. Identification of modal shifts in values raises the issue and the activity of what activism actually does; asking what should be intervened in; what should be changed? ; what practices of the past are chosen to be repeated and remembered? Why shouldn't we intervene 
and react and reject? So that when we think about affect, it is in its specific function as a modality, as it is framing a 'what if?' proposition as well as defining a situation.

\section{Temporal modal logics}

In narrativising a particular affect in terms of its modal logic, we ascribe a temporal measure. And this temporal measure may change over time. The temporal is a measure but also a value that communities and societies use for mapping out the duration of things. How long does a political regime last? How long did the community last? How long does a relationship last?

The temporal itself is a non-material abstract concept, but it names and gives form to matter, to a block - units of matter, units of experience in a Baradian sense. The duration of things enables a comparison of matter, that's made into material agency. And I think this is kind of a really interesting point to think about affect and agency, because one of the most significant invisible changes occurs in societies and communities, is in the ways in which the conceptualisation and then realisation of information and ideas, are given process and form.

How the temporal as an abstracted form is applied; as a measure between various relations of matter, can tell us a lot about the forms of political agency and this is one of the core factors that mobilises feminists' interaction. These are the processes that various organisations manifest, for example as media images that we see around political campaigns, in order to produce and maintain their political subjects and positions. The question is, how then do we articulate the temporality of matter as it forces itself into agential forms? There are a number of feminist thinkers that provide a genealogical framework of feminist durational concepts for consideration of how our current conditions of communication, transformational potentials, and a planetary ethical life may be reimagined, through the appropriation of agential forms (cf. Smith, 1987; Braidotti, 2002; Braidotti \& Hlavajova, 2018). A thinker who offers feminist actions through a temporal mode is Elizabeth Grosz, who works carefully through the Deleuzean inflected Bergsonian durational lexicon, as it might produce a more open appreciation of sexual difference (Grosz ,1994, p.2005). 
In this nod to both Deleuze (who often pointed out the untimeliness of his own work), and Bergson (Grosz's point is that the 'future' that feminism / feminist theory looks to is one that is 'bound up with change' (Grosz, 2010, p.48); Grosz reminds her readers, just as Mona Livholts and Maria Tamboukou point out (2015), of the importance of undertaking feminist work with a conceptual temporal framework in place, to enable the value of any empirical research to be made visible. Grosz thus advocates what she terms a 'revivifying activity' for feminist work; that is, in order to 'bring about a new future' then we can follow the example of Nietzsche and 'reactivate a past in the present', and feminist theory can thus 'leap into a future it does not control [only] through finding something untimely in the patriarchal present and past' (Grosz, 2010, p.49).

Grosz goes so far as to call upon feminism to direct itself toward change, and to 'changing itself as much as to changing to world' (2010, p.49), in order to develop what she calls 'feminist theory' as a discipline that will be 'a movement able to adequately address the real in all its surprising complexity' (Grosz, 2010, p.49). Articulating this real is what Grosz apologetically describes as 'what is most abstract and useless, what is most speculative and cosmological, in order that transformation, upheaval, and change become conceivable' (Grosz, 2010, p.51). This is a question for identifying not only the framework (epistemological and metaphysical) used to describe the 'truth' of the world; its ethical reality, or its collective, community ethos, but its modality. What are the modal practices engaged to generate the methods of practicing within the framework? For example, as Stacey Alaimo reflects about the modality of one of her edited books: "Material Feminisms seek to maintain modes of incisive and necessary discursive critique while also accounting for the many material forces that may interact with the discursive." (Alaimo 2014a, p.16)

There is potentially a problem of just narrativising in "real" time within the paradigms already established; thus repeating the status quo. This is what feminist education, and politics aim to avoid by attending to the affective modes in action. Grosz provides a practical, applied methodological framework to approach the empirical, to consider how this real of the present may be first of all mapped, and thus conceived and made 
perceivable. Articulating the modal framework is the task that new materialists often set themselves.

Grosz sets three tasks for feminist theory to embrace: First: A return to the question of materiality: 'We need to return to the question of matter, its forms, nature, and capacity, in order to address the direct objects of feminist investigation'. Secondly: A rethinking of 'biological questions' is required, in order to provide a direct - not linguistic - address of 'the material bases of the body's development (as male, as female, as raced, sexed, and historically encultured)' (Grosz, 2010, p.50). Grosz notes that we should look not only to those feminist theorists of science (and she names Evelyn Fox Keller, Anne Fausto-Sterling, Patricia Gowaty, and Sandra Hardy), but also to look to feminist cultural theorists, (Elizabeth A Wilson, N. Katherine Hayles, Catherine Waldby, Greit Vandermassen). Thirdly: Feminists need to become interested in 'material forces, 'discernible through their effects on [material] objects' (Grosz, 2010, p.50). Grosz notes that these forces are to be found in the 'unspoken assumptions of feminist politics and struggle', but primarily, she says, through a 'direct analysis' of 'the force of temporality' (Grosz, 2010, p.51). And this third point is where I will conclude this article, directing the work of feminist new materialisms to attend to the temporal modality in their accounts of affect and agency (the forces of temporality upon matter), such as we see exemplified in the work of Gala Pin within her community.

\section{Conclusion: feminist modal logics}

Rather than just being an assumed factor, or an event in history; the empirical and conceptual investigation into the constitution of a 'material environment' is what enables the political reality to be named. Examining a temporal mode of a community gives us their artefacts for measuring their histories, but also a genealogy of their value systems; their "truth". Rather than just being an assumed factor, the empirical and conceptual investigation into the constitution of what is our material environment, is what enables the political reality to be named- within and by its temporal modality. 
These are the coordinates of bodies, and things; as they are spatially, temporally, materially organised and represented; as artefacts and ecofacts, able to be observed, collected, collated, classified and thus located and put to work within infrastructures and systems. The affects produced through temporal modes include notions such as anticipation, anxiety, longing, hope, pain, and desire. Determining how political agency changes the forces of temporality, of course, is a [meta] question that allows us to make, first of all, some generalised observations under the thematics we cling to for example, in terms of a Cartesian perspectivalism. Extending the work of Arendt from a totalitarian genealogy to the terms of a neoliberalist framework, the demands for feminist activist interventions must be to work with the ethical demands of the posthuman algorithmic condition (see MacCormack 2012; Braidotti \& Hlavajova, 2018).

Modes and their modalities signal how agency comes to be organised, distributed, and shaped into both ephemeral and rigid infrastructures of governance. Attention to the modality of a political narrative - of the infrastructures of things, people, resources, materials- provides researchers, teachers, practitioners, students, and politicians, with the tools to action a legitimate ethical modality. The feminist new materialist practitioners refer to modal organisation in terms of the Bohr/Barad ontoepistemological investigation of 'how matter comes to matter' (Barad, 2003). Offering a critique of the epistemological narratives of practice-forming ontological 'truths' (that are used for example, to great effect in the work of Braidotti; Barad; Latour; Haraway; Alaimo, 2014b), is evidence of new materialism's deep commitment to transforming politics into a more ethical practice. New materialist strengths have been working on introducing and reintroducing discourses and practises of thinking and working with matter and its material and cognitive infrastructures, sometimes framed as empirical methodologies, or narrative research, but always concerning material modalities (eg. Alaimo \& Hekman, 2008; Bennet 2010; Hayles, 1999; Livholts \& Tamboukou, 2015; lovino \& Oppermann, 2014). No matter how abstracted or complex theory theoretical framework is, the new materialist theories continually serve to provoke and intervene and to remind theorist practitioners of all kinds, that all positions arrived from the material processes in the world. We need to continually ask what is matter? Why is 
it glorified or vilified? How do we undo the negative structures it has been put into service for that are destructive and harmful for the environment, and ask this very critical question of how matter comes to matter? The feminist activity engaging with such questions has led to very exciting possibilities, that Barad and Haraway and others opened up, such as how quantum discoveries of the 20th century opened the infinite dimensions for engaging with matter. Matter is an active, not passive agent, and to pay attention to its modal use requires an active engagement with the politics of the use of matter.

The ethical-political mantra of the new materialist position is to engage a material modal possibility, to ask - what if? This question enables the possibility of finding what will engender better conditions for all forms of life. Consideration of the question of which practices of the past that we choose to not be undone, and which ones do we choose to undo, and reform, is the task of educators and practitioners; to practice feminising politics. Rather than to only consider vernacular modes that imagine "futures" or deify "historical" narratives, instead consider the material and temporal modal constitution of your community and ask how your daily ethical ecology can be better constituted. The feminist modal logics enacted in the practical work of Gala Pin, and advocated by the conceptual model put forward by Elizabeth Grosz, are examples of feminist ethical philosophical, political practices which offer and remind us of how positive actions can be taken up; applied; and used to engage real change in the governance of political trajectories, and the sentient creatures creating communities.

With thanks to the peer reviewer's useful comments (Begonya Enguix Grau, Elisa Herrera Altamirano, and Ana Maria González Ramos), and the support of Beatriz Revelles-Benavente.

Research for this article was supported by COST Action IS1307, supported by the EU Framework Programme Horizon 2020. 


\section{Bibliography}

Alaimo, Stacy (2014a). Thinking as the Stuff of the World. O-Zone: A Journal of Object-Oriented Studies. (no.1) pp.13-21.

Alaimo, Stacy (2014b). Oceanic origins, plastic activism, and new materialism at Sea. Material Ecocriticism, lovino, S., \& Oppermann, S. (Eds.). Bloomington: Indiana University Press, pp.186-203.

Alaimo, Stacy \& Hekman, Susan (2008). Introduction: Emerging Models of Materiality in Feminist Theory. Material Feminisms, S. Alaimo and S. Hekman, (eds.): 1-19, Bloomington: Indiana University Press.

Arendt, Hannah (1958 [1951]). The Origins of Totalitarianism, Cleveland \& New York: Meridian Books.

Arendt, Hannah (2011). Essays in understanding, 1930-1954: formation, exile, and totalitarianism. Schocken.

Barad, Karen (2003). 'Posthumanist Performativity. Toward an Understanding of How Matter Comes to Matter'. Signs, 28(3): pp.801-831.

Bargetz, Brigitte (2018). Longing for agency: New materialisms' wrestling with despair. European Journal of Women's

Studies. https://doi.org/10.1177/1350506818802474

Braidotti, Rosi (2002). Metamorphoses: Towards a materialist theory of becoming. Cambridge: PolityPress.

Braidotti, Rosi (2008). In Spite of the Times: The Postsecular Turn in Feminism. Theory, Culture \& Society, 25(6), pp.1-

24. https://doi.org/10.1177/0263276408095542

Braidotti, Rosi \& Hlavajova, Maria (Eds.). (2018). Posthuman Glossary. London: Bloomsbury Publishing.

Brown, Wendy (2017). Walled states, waning sovereignty. Cambridge, MA: MIT Press. 
Colman, Felicity (2016). Digital Biopolitics: The Image of Life. Resisting Biopolitics: Philosophical, Political and Performative Strategies. S. Wilmer and A. Žukauskaitė (eds.). London \& New York: Routledge, pp.189-201.

Colman, Felicity (2018). Agency. New Materialism Almanac. http://newmaterialism.eu/almanac/a/agency.html Colman, Felicity (2019; [forthcoming]). Modality. "New Concepts for Materialism" special issue. I. Van der Tuin \& A. Nocek (Eds.) Philosophy Today.

Colman, Felicity, Bühlmann, Vera, O'Donnell, Aisliin \& van der Tuin, Iris (2018). Ethics of Coding: A Report on the Algorithmic Condition [EoC]. H2020-EU.2.1.1. INDUSTRIAL LEADERSHIP - Leadership in enabling and industrial technologies Information and Communication Technologies. Brussels: European Commission. 732407, https://cordis.europa.eu/project/rcn/207025_en.html. pp.1-54.

Degen, Monica (2017). Urban Regeneration and "Resistance of Place": Foregrounding Time and Experience. Space and Culture, 20(2), pp.141155. https://doi.org/10.1177/1206331217697136

Denning, Steve (2016). Trump And Authoritarian Propaganda. Forbes. (November 15) https://www.forbes.com/sites/stevedenning/2016/11/06/trump-andauthoritarian-propaganda/\#3b6512743e0a

Dixon-Román, Ezequiel (2017). Toward a hauntology on data: On the sociopolitical forces of data assemblages. Research in Education, 98(1), pp.44- 58. https://doi.org/10.1177/0034523717723387 ECV. (2016). Plan de Desarrollo Económico Ciutat Vella 2016-2021. https://bcnroc.ajuntament.barcelona.cat/jspui/bitstream/11703/108625/1/PDE_Ciut atVella-2016_cas.pdf

Fraser, Nancy (2016) Progressive Neoliberalism versus Reactionary Populism: A Choice that Feminists Should Refuse, NORA - Nordic Journal of Feminist and Gender Research, 24:4, pp.281-284, DOI: 10.1080/08038740.2016.1278263 
Glaser, Eliane (2018). Anti-politics: on the demonization of ideology, authority and the state. Watkins Media Limited.

Grosz, Elisabeth (1998). Thinking the new: Of futures yet unthought. symploke, 6(1): pp.38-55.

Grosz, Elisabeth (1994). Volatile bodies: Toward a corporeal feminism. Bloomington: Indiana University Press.

Grosz, Elisabeth (2005). Time travels: Feminism, nature, power. Durham, NC.: Duke University Press.

Grosz, Elisabeth (2010). The untimeliness of feminist theory. NORA—Nordic Journal of Feminist and Gender Research, 18(1), pp.48-51.

Harding, Sandra (1992) Rethinking standpoint epistemology: What is 'strong objectivity'? The Centennial Review 36(3): pp.437-470.

Hirschmann, Nancy \& McClure, Kristie (Eds.). (2010). Feminist Interpretations of John Locke. Penn State Press.

Illing, Sean (2019). A 1951 book about totalitarianism is flying off the shelves. Here's why. Vox. https://www.vox.com/conversations/2017/6/28/15829712/hannaharendt-donald-trump-brexit-totalitarianism

lovino, Serenella \& Oppermann, Serpil (eds.) (2014). Material Ecocriticism. Bloomington: Indiana University Press.

IPCC (2018). Summary for Policymakers. Global warming of $1.5^{\circ} \mathrm{C}$. An IPCC Special Report on the impacts of global warming of $1.5^{\circ} \mathrm{C}$ above pre-industrial levels and related global greenhouse gas emission pathways, in the context of strengthening the global response to the threat of climate change, sustainable development, and efforts to eradicate poverty [V. Masson-Delmotte, P. Zhai, H. O. Pörtner, D. Roberts, J. Skea, P. R. Shukla, A. Pirani, W. Moufouma-Okia, C. Péan, R. Pidcock, S. Connors, J. B. R. Matthews, Y. Chen, X. Zhou, M. I. Gomis, E. Lonnoy, T. Maycock, M. Tignor, T. Waterfield (eds.)]. World Meteorological Organization, Geneva, Switzerland. 
Jasanoff, Sheila \& Simmet, Hilton (2017). No funeral bells: Public reason in a 'posttruth' age. Social Studies of Science, 47(5), pp.751770. https://doi.org/10.1177/0306312717731936

Jiménez-Pacheco, Pedro (2018). After Planning, the Production of Radical Social Space in Barcelona: Real-Estate Financial Circuit and (De Facto) Right to the City. Urban Planning, 3(3), pp.83-104. https://doi.org/10.17645/up.v3i3.1360

Livholts, Mona \& Tamboukou, Maria (2015). Theoretical and Methodological Departures in Contested Fields of Study. Discourse and narrative methods: Theoretical departures, analytical strategies and situated writings. Sage. pp.9-26. Mahon, Rianne \& Robinson, Fiona (Eds.). (2011). Feminist ethics and social policy: Towards a new Global Political Economy of Care. Vancouver: University of British Columbia Press.

MacCormack, Patricia (2012). Posthuman ethics: Embodiment and cultural theory. London: Ashgate.

Patel, Tina \& Connelly, Laura (2019). 'Post-race' racisms in the narratives of 'Brexit' voters. The Sociological Review. https://doi.org/10.1177/0038026119831590 Pin, Gala (2017). Gala Pin and Whitney Stark in Conversation, with Ana González Ramos. 4th New Materialism Training School, "Art \& Activism” Curated by Beatriz Revelles-Benavente. Arts Santa Monica, Barcelona, Spain. (November 22). Transcriptions of the conversation by F.Colman.

Poser, Hans (2013). Technology and Modality. Printed Physics. - Metalithikum 1. Bühlmann \& Hovestadt (eds.) Vienna: Ambra: pp.71-112.

Smith, Dorothy (1987). The everyday world as problematic: A feminist sociology. University of Toronto Press.

Stang, Nicholas (2016). Kant's Modal Metaphysics. Oxford University Press. Stark, Whitney (2017). Gala Pin and Whitney Stark in Conversation, with Ana González Ramos. 4th New Materialism Training School, "Art \& Activism”. Curated 
by Beatriz Revelles-Benavente. Arts Santa Monica, Barcelona, Spain. (November 22). Transcriptions of the conversation by F.Colman. 